\title{
Some Poetic Multiple-Text Manuscripts of the Byzantine Era
}

\begin{abstract}
The paper focuses on some Byzantine manuscripts which consist of collections of Greek poetic texts and are linked to each other: (a) the lost poetic book of Constantine Cephalas and its main descendants, and (b) the poetic multiple-text manuscripts (MTMs) created in the circle of Maximus Planudes. A comparison between the structure and the purposes of some of these MTMs and the epigrammatic anthologies they include is also provided. In the final part of the paper, epigrammatic collections are also used as a case study on what MTMs can tell about the perception and the contexts in which the literary works they contain came to fruition.
\end{abstract}

First of all, I would like to clarify one possible ambiguity in the title of this paper. In Byzantine book production, poetic multiple-text manuscripts (or poetry MTMs) and prose MTMs did not form distinct and individual categories: our sources do not offer such a traceable typological distinction in the overall panorama and, as a matter of fact, prose and poetry were frequently mixed in MTMs.

Nonetheless, there are some important MTMs which contain only poetic texts. As a case study, I will focus on a group of them: their certain connection allows their analysis both as individual items and as links in a chain (where the chain is the transmission and the modification of a MTM through its descendants). Moreover, they were created in cultural contexts where the production of MTMs was remarkable, and they contain some texts that are particularly representative of the work conducted by Byzantine scholars. 


\section{Cephalas' book}

end of the ninth century

[lost]

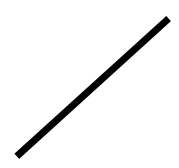

Heid. Pal. gr. 23 +

Par. Suppl. gr. 384

mid-tenth century

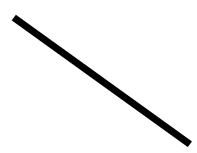

Marc. gr. 481

completed in 1299/1301

The progenitor of this (simplified: see below) stemma is lost but can be reconstructed with some confidence thanks to its descendants: it is the poetry book created by Constantine Cephalas, a professor at the school attached to the New Church in Constantinople during the last decades of the ninth century, later attested as protopapas ('first priest') at the Palace. ${ }^{1}$ The two descendants of Cephalas' book are independent and enlarged versions of their model; they were both also produced in Constantinople, but in different periods.

The lost Cephalas' book (or-in more cautious terms-the copies of Cephalas' book that represented the models of its descendants) contained Nonnus of Panopolis' poetic Paraphrase of the Gospel of John, Paul the Silentiary's Ekphraseis on Hagia Sophia and its ambo, a large anthology of epigrams and, possibly, Christodorus of Coptus' Ekphrasis on the Statues of the Baths of Zeuxippus. ${ }^{2}$ The epigrammatic anthology was created by Cephalas himself, who collected and rearranged some earlier collections. ${ }^{3}$ The metrical form (hexame-

1 On Cephalas see Cameron 1993, 254-255, Lauxtermann 2003, 86-87.

2 A detailed reconstruction of the book of Cephalas has been proposed by Lauxtermann 2007. We cannot, of course, be entirely certain that this lost book did not contain other texts, omitted by both its descendants.

3 On Cephalas' sources and on how he used them, see Cameron 1993, 121-159, Lauxterman 2003, 88-89; for an overall picture see also Maltomini 2019. On the structure of Cephalas' anthology see below, p. 208. 
ters and elegiacs) ${ }^{4}$ and the antiquity of the texts (all composed within the first Byzantine era) are the unifying features of the whole book.

The first descendant of Cephalas' book (the Heidelbergensis Palatinus Graecus 23 + Parisinus Supplementi Graeci 384) $)^{5}$ was completed within the midtenth century: two main blocks written by different scribes were joined, and the confection of the whole manuscript was accomplished by a redactor who is to be considered the maitre d'œuvre of this MTM. ${ }^{6}$ In its original form, the manuscript contained the following texts (I have marked those already present in Cephalas with an asterisk): <`Nonnus of Panopolis’ Paraphrase of the Gospel of John> (now lost, but registered in the index that opens the manuscript); ${ }^{\star}{ }^{\star} \mathrm{Paul}$ the Silentiary's Ekphraseis on Hagia Sophia and its ambo; some dogmatic epigrams by Gregory of Nazianzus; ${ }^{\star}$ Cephalas' epigrammatic anthology, enlarged (it is the famous Anthologia Palatina); John of Gaza's Tabula Mundi (a poem on a painting showing the cosmos); a collection of Anacreontea; some more epigrams, mostly already contained in the epigrammatic anthology. ${ }^{8}$ The compilers of this manuscript therefore added to Cephalas' book some epigrammatic and ekphrastic material, plus a collection of poems written in anacreontic meter. No cuts are detectable: Christodorus of Coptus' Ekphrasis on the Statues of the Baths of Zeuxippus was not removed by the scribes of the Palatinus, but included in the epigrammatic anthology. Since the Anacreontea were thought to be all by Anacreon, the overall slant of the collection remained the same as Cephalas'

4 Of course, this is not entirely true for the contents of the epigrammatic anthology, which includes some poems in different meters. Still, elegiacs (and hexameters) were largely the more common and characterizing meters of epigrammatic literature.

5 The manuscript was split in modern times with a completely artificial cut not respectful of the contents, and its two parts are now kept in two different libraries.

6 For the different scribes who contributed to the manuscript see Agati 1984. On the various parts and the completion of the manuscript, see Preisendanz 1911, lxxviii-cix; Irigoin 1997, 9496; van Dieten 1993-94. Cameron (1993, 300-328) proposed to identify the maitre d'oeuvreindicated with the letter $\mathrm{J}$ in modern editions of the Anthologia Palatina-with Constantine of Rhodes (see also Lauxtermann 2003, 84).

7 Although the index (see Preisendanz 1911, xliv-lii and Aubreton 1968, 47-56) shows some other inconsistences with the actual contents of the manuscript, there is no serious reason to think that the Paraphrase was never copied in the Palatinus; we can assume that at some point it was detached for a yet unclear reason. For this kind of physical modifications of MTMs see also below, pp. 205-206 and n. 15.

8 Some of these epigrams were inserted to fill the last quire of the Anacreontea; some others probably represented the last part of the epigrammatic anthology and were wrongly bound; the last group is a choice from the funerary epigrams of Gregory of Nazianzus already included in the epigrammatic anthology. 
(ancient poetry), while the uniformity of meters was disturbed. The book bears some traces of a 'work on the texts', mostly performed by the maitre d'œuvre who coordinated the completion of the manuscript, and by a contemporary corrector who collated the Palatinus with another copy of Cephalas' book. ${ }^{9}$ Some marginal notes in the manuscript show that both these scholars were directly acquainted with Cephalas: they had probably been his pupils, or his younger colleagues. ${ }^{10}$ Therefore, Cephalas' book and its first copy were chronologically close and were produced in the same context. They represent a significant and very representative output of the so-called 'prémier humanisme byzantin', ${ }^{11}$ when special attention was given to ancient texts.

The other descendant of Cephalas' book is a manuscript written entirely by Maximus Planudes by September 1301: the Marcianus Graecus 481. ${ }^{12}$ It contained the following texts: *Cephalas' epigram anthology (rearranged: it is the Anthologia Planudea); <Sylloge Theognidea>; Monostich gnomes (the so-called Menandri Sententiae); Leo Magister's poem on the Pythian hot springs (wrongly attributed in this manuscript to Paulus Silentiarius); some other epigrams and short poems, mostly didactic; an appendix to the epigram anthology; ^Nonnus of Panopolis' Paraphrase of the Gospel of John, preceded and followed by some other short poems. At the very end of the manuscript, a few short prose texts (the index of Plutarch's works and a grammatical note by Planudes) disrupt the 'whole poetic' nature of the manuscript.

The presence of an appendix to the epigrammatic anthology tells something about the history of this MTM: after having prepared the collection that opens the manuscript, Planudes was able to use another copy of Cephalas' book, and to extract from it another good number of epigrams (at least his first exemplar-and probably also the second-was therefore incomplete). He rearranged these epigrams in the same way as he did for the others, and copied them in his manuscript with some instruction to merge them with the 'first part' of the anthology in future copies. ${ }^{13}$

\footnotetext{
9 On the final redaction of the manuscript see above n. 6. On the corrector (indicated with the letter c in modern editions) see Preisendanz 1911, cx-cxl; Cameron 1993, 103-104, 108-113, 116-120.

10 See Cameron 1993, 108-116.

11 The definition of this period comes from the title of the still most accomplished (even if much discussed) attempt to describe it (Lemerle 1971).

12 The subscriptio of the manuscript bears an inconsistency between the year of indiction (1299) and the anno mundi (1301): on this matter see Cameron 1993, 76-77, and Maltomini 2008, $11 \mathrm{n}$. 2. For a description of the manuscript see Turyn 1972, I 90-96.

13 The first manuscript in which this merging was done is the Parisinus Graecus 2744, written by Demetrius Triclinius about 20 years after the Marcianus.
} 
In the Marcianus as we have it, the numbering of pages and quires shows a gap. The original full contents of the manuscript are reconstructable thanks to another manuscript: the Londinensis British Library Add. 16409. This manuscript - a 'twin' of the Marcianus produced in the Planudean circle and bearing interventions probably by Planudes himself- $-{ }^{14}$ reveals that the lost pages of the Marcianus contained the Sylloge Theognidea. ${ }^{15}$

Planudes modified a part of Cephalas' book by substantially rearranging the epigram collection. Also, he copied in his MTM some more ancient poetic texts, chosen, it seems, on the basis of mixed criteria of form and content. As for the form: both the Sylloge Theognidea and the Menandri Sententiae are, like the epigram anthology, made up of short pieces. As for the contents, besides maintaining the focus on ancient poetry already present in Cephalas, ${ }^{16}$ Planudes privileged moral and descriptive subjects. ${ }^{17}$ But these features do not correspond to a clear structure of the whole book. The Marcianus was primarily a 'workbook' and continued to be used as such over the years by its creator and owner. ${ }^{18}$ In cases like that, where the 'accumulation' of textual material is so important, it would be very interesting to know not just the date of the accomplishment of the manuscript registered in the subscriptio, but also all the 'intermediate dates' which marked its growth and modifications.

14 At first, the Londinensis was possibly intended as a copy of the Marcianus, but the comparison between the two manuscripts shows how the work on them was continued even later: some corrections (possibly by Planudes himself) were inserted in both manuscripts, while other interventions on the text are detectable in the Marcianus but not in the Londinensis, and vice versa. On this manuscript see Young 1955, 203-205; Turyn 1972-73, 417-419, 424; Cameron 1993, 345-350.

15 Young 1955, 203-204. Detaching these pages from the manuscript may have been a later choice by Planudes himself or by another owner who did not like the presence of the Sylloge in the manuscript; or (and perhaps more probably), the lacuna was produced by somebody who wanted to take possession of that work and physically extracted it from the manuscript (possibly rebinding it with other material to form a new, and now lost, MTM: this kind of 'recombination' is far from rare). The second hypothesis is corroborated by the fact that the extraction of the Sylloge left the Menandri Sententiae headless: something that Planudes, or a later owner of the Marcianus, might have avoided or fixed. For the physical modification of MTMs along their history, see also above n. 7.

16 Planudes was not aware that the poem on the Pythian hot springs was actually by Leo Magister and therefore Byzantine.

17 Thus, it is somewhat surprising that Planudes did not include Paul the Silentiary's Ekphraseis present in Cephalas' book. However, what happened with the epigrammatic anthology (see above p. 204) shows that the copies of Cephalas' book which Planudes was able to use were not in perfect condition.

18 The same is also true for the Londinensis: see above, n. 14 . 
It might be worthwhile to compare the features of the Marcianus with those of the two other poetic MTMs produced by Planudes and his entourage: together, they perfectly show how the collaboration between several people within the same cultural milieu led, especially in the Palaeologan era (1261-1453), to the production of MTMs. ${ }^{19}$ The first manuscript is the famous Laurentianus 32.16 (copied around 1280-1283). ${ }^{20}$ Planudes contributed only in part to the writing of this manuscript, collaborating with several other scholars/scribes; it was him, nonetheless, who shaped the book and 'signed it' in two subscriptiones inserted at different stages of the work. These subscriptiones, together with the contents of the manuscript, show that Planudes aimed at creating a book of hexametric poetry-mostly epic, didascalic and bucolic. ${ }^{21}$ The original 'core' of the manuscript (followed by the first subscriptio dated to 1280) contained Nonnus' Dionysiaca; Theocritus' Idyllia; Apollonius Rhodius' Argonautica; Hesiodus' Erga, Theogonia and Scutum; Oppian of Apamea Cynegetica and Oppian of Anazarbus' Halieutica. The second part (followed by the second subscriptio, probably written shortly after 1283) contains Moschus' poems; Nicander's Theriaca and Alexipharmaca; and Triphiodorus' Ilii Excidium. The very last part of the manuscript was added in the same milieu but a little later, and it contains some more poetic texts (PseudoPhocylides Sententiae and a collection of epigrams), which are less consistent with the rest of the book: once again, the MTM continues its evolution even after what was intended as the 'final word' had been written.

The second poetic MTM (still in need of an in-depth analysis) is the Vaticanus Graecus 915, completed before $1311 .{ }^{22}$ It was written by several scribes ${ }^{23}$, and it bears no direct interventions by Planudes' hand, but shows unmistakable contacts (both textual and palaeographic) with his 'circle'. The range of authors and works included is huge: Eudocia's Homerocentones; a summary of the Iliad; Theocritus' Syrinx; Orphic Sententiae; Sylloge Theognidea; Pseudo-Phocylides' Sententiae; Moschus' Europa; Musaeus' Hero et Leander; some excerpts from

19 On this subject, see Bianconi 2004.

20 The manuscript is described in Turyn 1972, I 28-39.

21 On this and other Byzantine manuscripts representing collections of specific genres see Canfora 1995, 230-233, Bianconi 2004, 324-362. It is worth noting that the other (not numerous) attempts at collecting various works of the same kind in the same manuscript mostly involved technical texts.

22 Useful information on this manuscript is provided in Pontani 2005, 293-297 (with previous bibliography). For the codicological description see Schreiner 1988, 125-137.

23 Schreiner 1988, 134 distinguished eight different scribes. Two of them have inserted subscriptiones 'closing' different parts of the manuscript: they bear no dates, but it is clear that the actual MTM is the product of collaboration and progressive accumulation of material. 
Eusthathius commentary in Dionysius Periegetes; Constantinus Manasses' Versus in Darium; Menandri Sententiae; some of Pindar's Epinicia; Hesiodus' Erga and Theogonia; Lycophron's Alexandra, Homer's Batrachomyomachia, Dionysius Periegetes' Orbis Descriptio, Theocritus' Idyllia; some passages of judicial and rhetoric content (representing prose 'intruders'); John Tzetzes' Antehomerica, Homerica and Posthomerica. The boundaries of genres are not clear, and the chronological spectrum is not limited to ancient poets (some Byzantine authors are consciously included), but a predominance of Homeric material and a remarkable attention to gnomic texts are noticeable. Moreover, many texts are accompanied by scholiastic material and commentaries useful for their study.

Even if they were not conceived as an actual 'set', the three Planudean MTMs we have seen cover a huge part of the ancient poetic texts known at that time. ${ }^{24}$ Still, they were primarily conceived as a mean to 'accumulate' texts that shared some detectable but rather general features. ${ }^{25}$ Even the Laurentianus, one of the highest 'specialised manuscripts' of the Byzantine era, does not aim at proper completeness or at entire coherence.

The primary function of MTMs as 'collectors' of texts does not foster stability, and Cephalas' book and its descendants confirm the already well-known general picture of how MTMs were handled. ${ }^{26}$ The analysis of the changes occurring from copy to copy shows many interventions operated mostly through additions: the only 'replica' in the group of manuscripts we are dealing with is the Londinensis, which was copied in the same context as the Marcianus and was probably conceived as a fair copy of it; but even in the Londinensis, subsequent modifications were introduced within few years, so that model and copy, although remaining in the same milieu, partially underwent separate evolutions. ${ }^{27}$

It is worth noting that, in the examples we have seen, the bulk of Cephalas' book (the epigram anthology and Nonnus' Paraphrase) stays the same in its descendants even if the connection between the two texts is not particularly strong. And even if the different additions to this 'core' inserted in the two descendants of Cephalas seem to seek a certain, generic coherence, the reshaping

24 Many texts are copied in two of these three MTMs. There is no overlap, however, between the two of them that show the direct intervention of Planudes (the Marcianus, all by his hand, and the Laurentianus, partially copied by him).

25 For some other MTMs sharing the same characteristics see Canfora 1995 and Bianconi 2004. 26 Maniaci 2004, 107; Andrist / Canart / Maniaci 2010. This awareness has triggered, in the last fifteen years, many interesting studies: see the rich bibliography and discussion provided by Crisci / Pecere 2004, Andrist / Canart / Maniaci 2013 and Friedrich / Schwarke 2016.

27 See above n. 14. 
of contents does not correspond with any substantial attempt at improving internal consistency.

The work on the texts proceeded in parallel with manuscript production and occurred in contexts of cultural vibrancy. It is not by chance that the two most important operations in the Byzantine transmission of the epigrammatic literature (the compilation of a huge anthology and, later, its rearrangement) were carried out in the ninth century and in the Palaeologan age respectively. And it should be emphasized that both Cephalas' and Planudes' books, besides gathering poetic texts, were also the means to record the respective 'versions' of relevant collections.

It might therefore be interesting to compare MTMs and anthologies, two products so common in (and characteristic of) the Byzantine era. ${ }^{28}$ Both were created within the same cultural framework, and both were based on the same principles: selection and arrangement of originally independent elements. We may try to verify if they were conceived and treated in the same way, focusing on the epigrammatic anthology created by Cephalas and included (and handled in a variety of ways) in the MTMs we have seen.

Cephalas used several earlier collections and arranged the material extracted from them into thematic books, each devoted to a broad subject: erotic (heterosexual) poems, votive, funerary, epideictic, ekphrastic, moral, sympotic and scoptic, erotic (pederotic and homosexual). ${ }^{29}$ Cephalas found a similar organisation in one of his sources and probably judged it useful to manage the huge quantity of epigrammatic material he dealt with. He also added to this 'core' some other materials based on previous collections: a book of Christian epigrams was put at the very beginning, and poems of epigraphic provenance were included in the funerary book..$^{30}$ There is no strict or homogeneous arrangement within each thematic book: Cephalas conceived his collection as a (didactic?) 'stroll' through the various (sub)genres of epigrammatic literature, a container offering the reader a wide panorama of the rich and diverse ancient production. ${ }^{31}$

28 On the so-called 'letteratura di raccolta' see Piccione 2003 and Piccione / Perkams 2003 (and especially the general introduction of the book). About the encyclopedic attitude in the Byzantine era see the important observations by Odorico 1990 and the treatment of this aspect in Van Deun / Macé 2011.

29 For the specific structure of each of these main books see the scheme in Cameron 1993, xvi. Cephalas also included a group of epigrams in 'unusual meters' and, possibly, some arithmetical problems in verse and some oracles (on the presence of this last section in Cephalas see Maltomini 2008, 189-195).

30 See the detailed reconstruction proposed by Lauxtermann 2007.

31 This attitude is explicitly stated in the short prefaces that open each book and that were written, in all probability, by Cephalas himself (see Maltomini 2011). 
The scribes of the Anthologia Palatina did not substantially modify Cephalas' epigrammatic anthology, whose structure remained the same. They nonetheless added some material to it, ${ }^{32}$ thus treating the epigram collection and the whole MTM in the same way: the original structure was not altered but significantly enlarged.

Planudes acted in a very different manner. He maintained the book division, just implementing some changes to Cephalas' structure: he eliminated the whole book of homosexual epigrams (while the heterosexual erotic book was drastically reduced, but maintained), and he merged the epideictic and the protreptic books. The major interventions were applied to the internal arrangement of the books: judging his model quite disordered, ${ }^{33}$ Planudes divided each book in many 'chapters', each one devoted to a specific subject and equipped with a title; the chapters were put in alphabetical order (by title) inside each book. So, for example, the third book (devoted to funerary epigrams), is articulated in 32 chapters $^{34}$ on various 'categories of dead men' (e.g. athletes, women, wreckage victims, poets, philosophers, etc.). While reworking his model that way, Planudes eliminated some epigrams which were similar to others (and therefore 'superfluous'), and, as I have already mentioned, suppressed many erotic pieces that were in his opinion obscene and could not be 'corrected' so as to become more acceptable. Planudes' work on the anthology was therefore very intrusive and produced a strictly ordered (and bowdlerised) collection. With regard to the research carried out for this paper, it is important to observe that Planudes also rearranged in a very similar way another collection included in the Marcianus: the monostich gnomes known as 'Menandri Sententiae.' He created several thematic kephalaia containing all the monostichs on a same subject, and put them in alphabetical order. ${ }^{35}$ The operations performed by Planudes on these collections have to be contextualized in the broader picture of the activities of this central figure of the so-called Palaeologan

32 Christodorus of Coptus' Ekphrasis on the Statues of the Baths of Zeuxippus (possibly already present in the book of Cephalas: see above p. 194) was incorporated in the epigrammatic anthology, and the funerary poems by Gregory of Nazianzus were copied at the end of Cephalas' funerary book. See above p. 195 and n. 8 for the additions at the end of the anthology.

33 This opinion is explicitly expressed by Planudes in a note in the Marcianus. He does not mention Cephalas as the compiler of the anthology, and we are not able to determine if this was an intentional omission or if he was not aware of this information.

3428 in the first part of the anthology, and four more in the second part later added (see above p. 204).

35 On the Planudean 'edition' of the Menandri Sententiae see Pernigotti 2008, 101-152. 
Renaissance. ${ }^{36}$ Planudes was a tireless seeker of ancient literary works (he rediscovered some important texts that were no longer known in Byzantium) and a learned -if not always cautious or respectful-editor of them: it is well-known how he and his co-workers played a crucial role in the transmission of ancient literature through the Byzantine era. Besides being a censor, the 'Dr. Bowdler of Byzantium' (as Douglas Young has called him) ${ }^{37}$ was also a systematiser: these two attitudes are combined in his treatment of the epigram anthology and obtained a great success. The Planudean Anthology was copied many times and it remained basically stable along its transmission, replacing Cephalas' collection and representing the epigrammatic anthology for several centuries. ${ }^{38}$

Anthologies therefore show the possible role played by authority and structure: an anthology made by an authoritative compiler (Cephalas for the people who created the Palatinus; Planudes for his co-workers and for the next generations) is more protected, less liable to modifications and therefore more stable. A structure based on thematic books such as the one chosen by Cephalas was in line with the Byzantine mindset, and was therefore maintained in its descendants. And a rigid structure such as that built up by Planudes within the thematic books is less exposed to the risk of intrusive modification than a loose one.

As we have seen, the attitude towards MTMs does not develop such a tendency to stabilisation: even Planudes, the systematiser par excellence, was not interested in creating MTMs arranged according to a 'strong' structure. ${ }^{39}$ The treatment of anthologies (texts) and of MTMs (containers of texts) seems, in this respect, different, and it might point to a difference between these two kinds of products in the Byzantine era. The texts were the object of careful work, and several collections (made of smaller pieces and potentially fluid) were assembled and modified to reach what was thought to be their best shape. The MTMs, on the other hand, were basically the instrument to perform preserve and, possibly, circulate this

36 For a sketch of this period and of its main scholars see Pontani 2015, 403-434. On Planudes see specifically 409-415 and Ferroni 2015, 9-22, with previous bibliography.

37 Young 1955, 206. On Planudes' attitude to censorship and bowdlerization (also intended as means to integrate classical literature in the culture of his time) see Karla 2006.

38 The Anthologia Palatina remained unknown for many centuries, and until its 'rediscovery' at the beginning of the seventeenth century (see Aubreton 1980), the Planudean Anthology represented the most complete source for ancient epigrammatic poetry.

39 The case of manuscripts containing several works of the same author is obviously different, as is well shown by Planudes' treatment of Plutarch's works. Planudes handled this corpus with the systematising attitude he applied to collections, and he entrusted his work to some beautifully produced manuscripts: the Parisinus Graecus 1671 and the Parisinus Graecus $1674+$ Vaticanus Graecus 139 (see Manfredini 1992). 
work; any attempt of internal coherence is not pursued with particular attention, and might be swiftly altered.

One last observation applies to how MTMs may prove useful to understand the perception and the use of certain texts. As a matter of fact, one and the same literary work has often been connected, in different moments or contexts, to different 'literary categories' and to different purposes. In the case of epigrammatic literature, these changes are reflected both in the contents of anthologies and in the contents of MTMs including these anthologies. Evidence in this respect is provided not only by the big anthologies we have dealt with in this article, but also by the so-called Syllogae Minores, much smaller collections deriving mainly from Cephalas' and Planudes' anthologies and transmitted in several MTMs from the twelfth to the sixteenth century. ${ }^{40}$ Until the end of the thirteenth century, the whole wide range of topics covered by the epigrammatic literature was reflected in the collections: this was, as we have seen, one of the aims-and possibly the more important-of Cephalas' selection. From Planudes onwards (and especially after him, in the Syllogae Minores deriving from his anthology), the selection privileged epigrams having a moral content. Moral in a wide, but nonetheless limited, sense: the compilers chose those epigrams that, in their opinion, tell something about human life and provide short and useful reflections, so that the epideictic and protreptic genres were the most appreciated. ${ }^{41}$ The radical cuts operated by Planudes to the erotic material are certainly revealing, and another meaningful example is provided by the Syllogae indicated in modern editions with the sigla $\mathrm{E}$ and $\Sigma^{\pi}{ }^{42}$ They both derive from a common source (an abridged copy of Cephalas) but have a significantly different slant: $\Sigma^{\pi}$, written during the twelfth century, bears some erotic epigrams, while E, transmitted in manuscripts of the end of the fifteenth century, ignores them.

If, in parallel, we look at the overall content of MTMs including epigrams anthologies, we see that this change of perception (and/or use) of epigrammatic literature is entirely confirmed: in manuscripts down to the late thirteenth century (including Planudes' Marcianus), epigram collections are associated with other poetic texts, so that a formal criterion seems to prevail; when principles involving contents are applied, the epigram seems to be perceived mostly as a descriptive genre. Later, epigrams are mostly associated with texts of a moral content, and they often appear also in MTMs conceived for an educational purpose. ${ }^{43}$

40 On these small collections see Maltomini 2008.

41 See Maltomini 2008, 185-186.

42 On the nature and contents of these two collections, see Maltomini 2008, 79-110.

43 Maltomini 2008, 185-187. 
This same approach is applicable to any text transmitted in MTMs, representing another interesting way to use the evidence provided by this kind of manuscripts.

\section{References}

Agati, Maria Luisa (1984), 'Note paleografiche all'Antologia Palatina', in Bollettino dei Classici s. III 5: 43-59.

Andrist, Patrick / Canart, Paul / Maniaci, Marilena (2013), La syntaxe du codex. Essai de codicologie structurale (Bibliologia: Elementa ad Librorum Studia Pertinentia, 34), Turnhout: Brepols.

Aubreton, Robert (1968), 'La tradition manuscrite des épigrammes de l'Anthologie grecque', in Révue des Études Anciennes, 70: 32-82.

Aubreton, Robert (1980), 'La tradition de l'Anthologie Palatine du XVIe au XVIIle siècle', in Révue d'Histoire des Textes, 10: 1-53.

Bianconi, Daniele (2004), 'Libri e mani. Sulla formazione di alcune miscellanee dell'età dei Paleologi', in Crisci / Pecere (eds) 2004, 311-363.

Cameron, Alan (1993), The Greek Anthology from Meleager to Planudes. Oxford: Clarendon Press.

Canfora, Luciano (1995), 'Le collezioni superstiti', in Giuseppe Cambiano / Luciano Canfora / Diego Lanza (eds), Lo spazio letterario della Grecia antica, II. Roma: Salerno Editrice, 95261.

Crisci, Edoardo / Pecere, Oronzo (eds) (2004), Il codice miscellaneo. Tipologie e funzioni, Atti del Convegno Internazionale (Cassino, 14-17 maggio 2003). Cassino: Università degli Studi di Cassino (= Segno e Testo 2).

Ferroni, Lorenzo (2015), Maximi Planudis e Platonis dialogis compendia. Bologna: Pàtron. Michael Friedrich / Cosima Schwarke (eds) (2016), One-Volume Libraries: Multiple-Text and Composite Manuscripts (Studies in Manuscripts Cultures, 9). Berlin, Boston: De Gruyter.

Irigoin, Jean (1997), 'L'Anthologie grecque', in Jean Irigoin, Tradition et critique des textes grecs. Paris: Les Belles Lettres, 89-103.

Karla, Grammatiki A. (2006), 'Maximos Planudes: Dr Bowdler in Byzanz? Zensur und Innovation im späten Byzanz', Classica et Mediaevalia, 57: 213-238.

Lauxtermann, Marc D. (2003), Byzantine Poetry from Pisides to Geometres. Texts and Contexts. Vienna: Verlag der Österreichischen Akademie der Wissenschaften.

Lauxtermann, Marc D. (2007), 'The Anthology of Cephalas', in Martin Hinterberger / Elisabeth Schiffer (eds), Byzantinische Sprachkunst. Studien zur byzantinischen Literatur gewidmet Wolfram Hörandner zum 65. Geburtstag. Berlin: De Gruyter, 194-208.

Lemerle, Paul (1971), Le premier humanisme byzantin: Notes et remarques sur enseignement et culture à Byzance des origines au $X^{e}$ siècle. Paris: Les Presses Universitaires de France.

Maltomini, Francesca (2008), Tradizione antologica dell' epigramma greco. Le Sillogi Minori di età bizantina e umanistica. Roma: Edizioni di Storia e Letteratura.

Maltomini, Francesca (2011), 'Selezione e organizzazione della poesia epigrammatica fra IX e X secolo: la perduta antologia di Costantino Cefala e l'Antologia Palatina', in Van Deun / Macé 2011, 109-124. 
Maltomini, Francesca (2019), 'Greek Anthologies from the Hellenistic Age to the Byzantine Era: a Survey', in Christer Henriksén (ed.), A Companion to Ancient Epigram (Blackwell Companions to the Ancient World). Malden (MA): Wiley-Blackwell, 211-227.

Manfredini, Mario (1992), 'Il Plutarco di Planude', in Studi Classici e Orientali, 42: 123-125.

Maniaci, Marilena (2004), 'Il codice greco “non unitario". Tipologie e terminologia', in Crisci / Pecere (eds) 2004, 75-107.

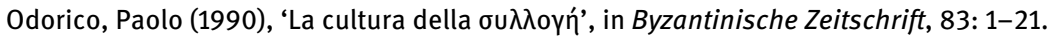

Pernigotti, Carlo (2008), Menandri Sententiae. Firenze: Olschki.

Piccione, Rosa Maria (2003), 'Scegliere, raccogliere e ordinare. Letteratura di raccolta e trasmissione del sapere', in Enrico Valdo Maltese (ed.), Bisanzio fra storia e letteratura. Brescia: Morcelliana, 44-63.

Piccione, Rosa Maria / Perkams, Matthias (eds) (2003), Selecta Colligere I. Akten des Kolloquiums Sammeln, Neuordnen, Neues Schaffen. Methoden der Überlieferung von Texten in der Spätantike und in Byzanz (Jena, 21.-23. November 2002). Alessandria: Edizioni dell'Orso.

Pontani, Filippomaria (2005), Sguardi su Ulisse. La tradizione esegetica greca all'Odissea. Rome: Edizioni di Storia e Letteratura.

Pontani, Filippomaria (2015), 'Scholarship in the Byzantine Empire (529-1453)', in Franco Montanari / Stephanos Matthaios / Antonios Rengakos (eds), Brill's Companion to Ancient Greek Scholarship, I. Leiden, Boston: Brill, 297-455.

Preisendanz, Karl (1911), Anthologia Palatina. Codex Palatinus et codex Parisinus phototypice editi. Leiden: A.W. Sijthoff.

Schreiner, Peter (1988), Codices Vaticani Graeci: codices 867-932, Città del Vaticano: Biblioteca Apostolica Vaticana

Turyn, Alexander (1972), Dated Greek Manuscripts of the Thirteenth and Fourteenth Centuries in the Libraries of Italy. Urbana, Chicago, London: University of Illinois Press.

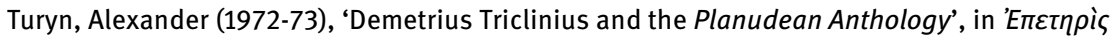

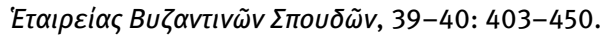

van Deun, Peter / Macé, Caroline (eds) (2011), Encyclopedic Trends in Byzantium? Proceedings of the International Conference held in Leuven, 6-9 May 2009. Leuven: Peeters.

van Dieten, Jean Louis (1993-94), 'Zur Herstellung des Codex Palat. gr. 23 / Paris. Suppl. Gr. 384', in Byzantinische Zeitschrift, 86-87: 342-362.

Young, Douglas C. C. (1955), 'On Planudes' Edition of Theognis and a Neglected Apograph of the Anthologia Planudea', in La parola del passato, 10: 197-214. 
